\title{
PENGARUH KUALITAS PELAYANAN WEBSITE DJP TERHADAP KEPUASAN PENGGUNA DENGAN MODIFIKASI E GOVQUAL
}

\author{
Dessanti Putri Sekti Ari ${ }^{1}$, Latifah Hanum ${ }^{2}$ \\ Fakultas Ilmu Administrasi, Universitas Brawijaya ${ }^{12}$ \\ Email: dessantiputrisa@gmail.com¹, latifahhanum@ub.ac.id²
}

\begin{abstract}
One of the DGT e-government is the DGT website.. The DGT website contains the latest information on taxes, announcements, tax applications, the latest laws and regulations, press releases, DGT activities, customer service, and information about the DGT organizational structure. The existence of the website is expected to facilitate communication between taxpayers and the tax authorities as well as a means of facilitating the public to get the latest information related to taxation in Indonesia. However, some people still complain about this website service, one of which is that the website is still difficult to access. This complaint can potentially reduce user satisfaction. Therefore, this study aims to determine the effect of service quality on user satisfaction of the DGT website with e govqual modification. The dimensions used to measure this service's quality are efficiency, trust, reliability, citizen support, and system quality. Students are one of the DGT website users. Therefore, the population in this study were active undergraduate taxation students. The sampling method used was a random sampling system. This study uses an online survey to obtain data. The statistical tool used in this research is the SmartPLS program. This study's results indicate that each of the e govqual dimensions and its significant modification forms the system quality variable. And system quality variables affect user satisfaction.
\end{abstract}

Keywords: service quality, user satisfaction, and e govqual

\begin{abstract}
Abstrak
Salah satu e government yang dimiliki oleh DJP adalah website DJP. Website DJP berisi tentang informasi terkini seputar pajak, pengumuman, aplikasi pajak, peraturan perundang-undangan terbaru, siaran pers, kegiatan DJP, layanan customer service dan informasi struktur organisasi DJP. Keberadaan website diharapkan dapat memudahkan komunikasi antara Wajib pajak dengan fiskus serta sebagai sarana yang memudahkan masyarakat untuk mendapatkan informasi terbaru terkait dengan perpajakan di Indonesia. Namun, beberapa masyarakat masih mengeluh atas layanan website ini, salah satunya adalah website masih susah diakses. Keluhan ini dapat berpotensi menurunkan kepuasan pengguna. Oleh karena itu penelitian ini bertujuan untuk mengetahui pengaruh kualitas pelayanan terhadap kepuasan pengguna website DJP dengan modifikasi e govqual.. Adapun dimensi yang digunakan untuk mengukur kualitas pelayanan ini adalah efisiensi, reliabilitas, kepercayaan, dan dukungan masyarakat, dan kualitas system. Mahasiswa adalah salah satu pengguna website DJP. Oleh karena itu, populasi yang digunakan dalam adalah mahasiswa aktif S1 Perpajakan.. Metode pengambilan sample yang digunakan adalah system random sampling. Penelitian ini menggunakan survei online untuk mendapatkan data. Alat statistik yang digunakan untuk mengolah data penelitan ini adalah program SmartPLS. Hasil penelitian ini menunjukkan bahwa masing-masing dimensi e govqual dan modifikasinya signifikan membentuk variabel kualitas sistem. Dan varibel kualitas sistem berpengaruh terhadap kepuasan pengguna.
\end{abstract}

Kata kunci : Kualitas layanan, kepuasan pengguna, dan e govqual 


\section{A.}

\section{PENDAHULUAN}

Pemerintah Indonesia dianjurkan menyeenggarakan $e$ government sejak tahun 2003. Hal ini dimulai dengan dikeluarkannya Instruksi Presiden No. 3 Tahun 2003 tentang Kebijakan dan Strategi Nasional. Penggunaan $e$ government dilakukan untuk mendukung reformasi tata kelola pemerintahan. Dengan adanya $e$ government diharapkan dapat mempererat hubungan dengan masyakat melalui teknologi dengan penyediaan website, aplikasi, e-mail dan mobile computing lainnya.

Saat ini e government telah banyak digunakan oleh instansi-instansi pemerintah. Salah satu instansi yang menggunakan $e$ government adalah Direktorat Jenderal pajak. Direktorat Jenderal pajak adalah salah satu lembaga pelayanan masyarakat yang telah menerapkan e government. Beberapa $e$ government yang digunakan oleh DJP adalah Website Ditjen Pajak, program aplikasi monitoring pelaporan dan pembayaran pajak, program aplikasi e-registration, program aplikasi e SPT, program aplikasi e filling, dan Sistem Informasi Geografis. Website DJP adalah salah satu $e$ government berisi tentang informasi terkini seputar pajak, pengumuman, aplikasi pajak, siaran pers, peraturan perundang-undangan terbaru, kegiatan DJP, layanan customer service serta informasi struktur organisasi DJP. Website DJP dapat dikses melalui situs pajak.go.id. Dengan adanya website diharapkan masyarakat dapat mendapatkan informasi perpajakan dengan lebih mudah.

Namun, sepertinya masih banyak masyarakat yang jarang memanfaatkan website ini. Sehingga informasi dan pengetahuan pajak yang dimiliki oleh masyarakat rendah. Selain itu, beberapa masyarakat juga memberi keluhan terhadap website DJP. Salah satu keluhan terhadap website DJP terkait dengan sulitnya website untuk diakses, dan kendala website error. Keluhan ini berpotensi menurunkan kepuasan pengguna. Oleh karena itu, perlu diketuhi tentang kepuasan pengguna website DJP.

Kepuasan pengguna merupakan perasaan senang atau kecewa seseorang setelah membandingkan antara persepsi terhadap kinerja atau hasil suatu produk dan harapanharapannya (Kotler \& Kevin Lane Keller, 2002: 42). Salah satu hal yang mempengaruhi kepuasan pengguna adalah kualitas pelayanan. Kualitas pelayanan kualitas pelayanan adalah upaya pemenuhan kebutuhan dan keinginan pelanggan, serta ketetapan penyampaiannya untuk mengimbangi harapan pelanggan. Kualitas pelayanan tradisional berbeda dengan kualitas pelayanan e government. Kualitas pelayanan traditional dapat diukur dengan dimensi SERVQUAL yang dikembangkan oleh (Parasuraman et al., 1988; Parasuraman et al., 1985). SERVQUAL terdiri dari lima dimensi yaitu tangible, reliability, responsiveness, assurancedan emphaty. Beberapa studi menerapkan model SERVQUAL untuk mengukur e service quality. Namun, penerapan model SERVQUAL dalam konteks e service quality menjadi kurang efisien (Parasuraman et al., 1985). Dalam hal ini e-service quality adalah penerapan e government dalam bentuk website. Oleh karena itu penelitian ini akan menggunakan pengukuran kualitas pelayanan yang dikembangkan oleh (Papadomichelaki \& Mentzas, 2012) yang disebut dengan $e$ Govqual. Dimensi e Govqual yang ditemukan ada 4, yaitu efisiensi, kepercayaan, reliabilitas, dan dukungan masyarakat (Papadomichelaki \& Mentzas, 2012). Peneliti melakukan modifikasi dalam e-Govqual. Modifikasi dilakukan dengan menambahkan dimensi kualitas system dari Li dan Shang (2020)

e-Govqual adalah instrument yang dikembangkan untuk situs web pemerintah (Papadomichelaki \& Mentzas, 2012). Oleh karena itu, Papadomichelaki dan Mentzas (2012) menyarankan agar subjek yang diteliti dalam penelitian adalah orang-orang yang berpotensi tinggi mengunakan e government. Salah satu pengguna e government website DJP yang potensil adalah mahasiswa perpajakan. Hal ini dikarenakan mahasiswa harus selalu mencari informasi terkini di bidang perpajakan baik kasus maupun peraturan perundangundangan. Selain itu, banyak para mahasiswa Perpajakan yang menjadi relawan pajak yang sangat perlu mengakses website DJP dalam menjalankan tugasnya. Relawan pajak adalah masyarakat umum yang membantu para wajib pajak dalam pelaporan SPT.

Berdasarkan uraian di atas, maka fokus penelitian ini adalah untuk mengetahui pengaruh kualitas pelayanan terhadap kepuasan pengguna website DJP dengan modifikasi $e$ Govqual. Dimensi yang digunakan untuk mengukur kualitas pelayanan ini adalah efisiensi, kepercayaan, reliabilitas, dukungan masyarakat, dan kualitas sistem. 
Mahasiswa Program Studi S1 perpajakan Universitas Brawijaya adalah pengguna aktif website DJP. Mahasiswa memanfaatkan website DJP untuk mencari informasi dan peraturan perpajakan terkini untuk tugas-tugas perkuliahan. Selain itu beberapa mahasiswa Program Studi S1 Perpajakan merupakan mahasiswa relawan pajak yang bertugas untuk membantu wajib pajak melaporkan SPT. Sehingga mereka juga pernah menggunakan aplikasi yang disediakan oleh website DJP. Oleh karena itu subjek penelitian ini adalah mahasiswa S1 Perpajakan Universitas Brawijaya yang pernah menggunakan website DJP.

\section{B. KAJIAN PUSTAKA Kualitas Pelayanan}

Kualitas pelayanan merupakan upaya untuk memenuhi kebutuhan dan keinginan pelanggan, serta ketetapan penyampaiannya untuk mengimbangi harapan pelanggan (Nasution, 2004: 47). Pelayanan yang unggul diartikan sebagai suatu sikap atau cara karyawan dalam melayani pelanggan secara memuaskan (Nasution, 2004: 49). Kualitas pelayanan bukanlah dilihat dari sudut pandang pihak penyelenggara atau penyedia layanan, melainkan berdasarkan persepsi pelanggan, karena pelangganlah yang mengkonsumsi dan merasakan pelayanan yang diberikan sehingga merekalah yang seharusnya menilai dan menentukan kualitas pelayanan. Beberapa pengertian yang terkait dengan definisi kualitas jasa pelayanan yaitu: Exelllent ,Customer Service, Quality, Levels, Consistent Delivery (Yamit, 2010: 22).

\section{Kepuasan Pelanggan}

Kepuasan diartikan sebagai perasaan senang atau kecewa seseorang yang timbul karena membandingkan kinerja yang dipersepsikan (kenyataan yang dialami) terhadap ekspektasi (harapan) mereka (Kotler, 1997: 40). Peter dan Olson dalam Usmara mendefinisikan kepuasan atau ketidakpuasan merupakan perbandingan antara harapan kinerja sebelum membeli dan persepsi kinerja yang diterima konsumen setelah membeli (Usmara, 2003: 123). Ketidakpuasan terhadap suatu produk atau layanan suatu organisasi dapat menyebabkan masalah dengan kualitas produk atau layanan tersebut. Dari beberapa pengertian kepuasan tersebut, maka dapat diasumsikan bahwa kepuasan adalah perasaan senang atau kecewa yang dimiliki seseorang sebagai hasil perbandingan antara kinerja yang dipersepsikan (kenyataan yang dialami) dengan harapan mereka.

\section{E-govqual}

E-Government Quality (E-GovQual) adalah metode untuk mengukur sistem informasi yang berbasis elektronik dalam memberikan layanan terhadap masyarakat. Instrumen E-GovQual dikembangkan dengan mengukur kualitas layanan yang diberikan oleh layanan E-Government berdasarkan perspektif pengguna akhir atau masyarakat. E-GovQual terdiri dari 6 (enam) dimensi, yaitu dimensi kemudahan penggunaan (ease of use), dimensi kepercayaan (trust), dimensi fungsi dan interaksi formulir (functionality of the interaction environment), dimensi keandalan (reliability), dimensi isi dan tampilan informasi (content and appearance of information) dan dimensi pendukung (citizen support).

\section{E-government}

$E$ government adalah penggunaan teknologi informasi oleh lembaga pemerintah (seperti Wide Area Network, internet, dan komputasi seluler) yang memiliki kemampuan untuk mengubah hubungan dengan warga negara, bisnis, dan badan pemerintahan lainnya. Berdasarkan definisi tersebut, e government merupakan teknologi informasi yang digunakan di lembaga pemerintah atau lembaga publik. Tujuan penggunaan teknologi informasi tersebut adalah untuk menciptakan hubungan yang lebih efisien, efektif, produktif, dan responsif antara pemerintahan, pelaku bisnis dan masyarakat. Dengan demikian, hasil yang diperoleh melalui $e$ government, yaitu terciptanya pemerintahan yang baik korupsi yang berkurang, transparansi yang meningkat, kenyamanan yang lebih besar, peningkatan penerimaan negara, dan atau pengurangan biaya. Ada 4 model hubungan e government, yaitu :government to citizen, government to business, governmenr to government, dan government to employees (Schlæger, 2013).

\section{Website DJP}

Website resmi utama milik Direktorat Jenderal Pajak (DJP) Kementerian Keuangan dapat diakses melalui situs www.pajak.go.id. Website ini berisi tentang informasi terkini seputar pajak. Adapun informasi-informasi yang dapat dia seperti peraturan perundang- 
undangan terbaru, seluruh aplikasi pajak milik DJP, siaran pers, pengumuman, kegiatan DJP, layanan customer service hingga informasi mengenai struktur organisasi DJP.

\section{MODEL PENELITIAN}

Kualitas layanan dapat memengaruhi kepuasan pelanggan, bahkan secara langsung atau tidak langsung juga dapat mempengaruhi loyalitas pelanggan. Hal ini diperkuat lagi oleh penelitian yang telah dilakukan dalam pengukuran kualitas layanan berbasis online di industri perbankan dan industri lainnya bahwa dimensi kualitas layanan yang berdasarkan teknologi ternyata berpengaruh terhadap kepuasan dan kesetiaan pelanggan (Ganguli \& Roy, 2011). Mereka menemukan bahwa kualitas layanan dengan dukungan teknologi yang mudah dan reliabel (e-service quality) mempunyai pengaruh positif terhadap kepuasan dan loyalitas pelanggan. Hal ini sesuai dengan pernyataan John dalam Lupiyoadi bahwa persepsi positif dari pelanggan dapat diciptakan dari kualitas layanan yang diberikan, yang pada akhirnya akan mengacu kepada suatu kepuasan dan loyalitas pelanggan untuk menggunakan produk atau jasa tersebut (Lupiyoadi Rambat, 2001).

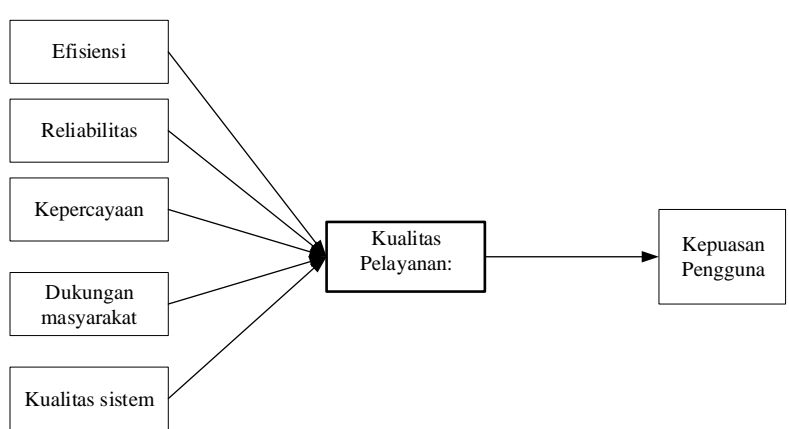

Gambar 1 Model Penelitian

Oleh karena itu.. hipotesis dalam penelitian ini adalah : Kualitas pelayanan berpengaruh terhadap kepuasan wajib pajak

Berikut ini adalah definisi variabel dan pengukuran:

1. Kualitas Pelayanan

Definisi kualitas pelayanan adalah upaya pemenuhan kebutuhan dan keinginan pelanggan, serta ketetapan penyampaiannya untuk mengimbangi harapan pelanggan Dalam penelitian ini kualitas pelayanan akan diukur melalui indikator:

\section{a. Efisiensi}

Efisiensi didefinisikan sebagai kemudahan menggunakan situs dan kualitas informasi yang disediakannya (Papadomichelaki \& Mentzas, 2012). Item pertanyaan yang digunakan untuk mengukur indikator ini mengacu pada penelitian Papadomichelaki dan Mentzas (2012), yaitu :

1) Struktur situs website DJP ini jelas dan mudah diikuti.

2) Mesin pencari situs website DJP ini efektif.

3) Menu-menu (peta situs-situs) Website DJP ini tertata dengan baik.

4) Situs Website DJP ini disesuaikan dengan baik untuk kebutuhan pengguna individu.

5) Informasi yang ditampilkan di situs website DJP ini cukup rinci.

6) Informasi yang ditampilkan di situs website DJP ini masih baru.

7) informasi tentang cara mengisi formulir (contoh cara pengisisan spt melalui e filling) yang disediakan oleh situs website djp sudah cukup jelas.

\section{b. Reliabilitas}

Keandalan didefinisikan sebagai kelayakan dan kecepatan mengakses, menggunakan, dan menerima layanan situs (Papadomichelaki \& Mentzas, 2012). Item pertanyaan yang digunakan untuk mengukur dimensi ini mengacu pada penelitian Papadomichelaki dan Mentzas (2012), yaitu :

1) Formulir di situs website DJP ini diunduh dalam waktu singkat.

2) Situs website DJP ini tersedia dan dapat diakses kapan pun Anda membutuhkannya.

3) Situs website DJP ini melakukan layanan dengan sukses atas permintaan pertama.

4) Situs website DJP ini menyediakan layanan tepat waktu.

5) Halaman situs website DJP diunduh dengan cukup cepat. 
6) Situs website DJP ini bekerja dengan baik dengan browser default Anda.

\section{c. Kepercayaan}

Kepercayaan didefinisikan sebagai sejauh mana warga negara meyakini bahwa situs tersebut aman dari gangguan dan melindungi informasi pribadi (Papadomichelaki \& Mentzas, 2012). Item pertanyaan yang digunakan untuk mengukur dimensi ini mengacu pada penelitian Papadomichelaki dan Mentzas (2012), yaitu :

1) Akuisisi username dan password di situs website DJP ini aman.

2) Hanya data pribadi yang diperlukan yang disediakan untuk otentikasi di situs website DJP ini.

3) Data yang disediakan oleh user (pengguna) di situs website DJP ini diarsipkan dengan aman.

4) Data yang disediakan di situs website DJP ini digunakan hanya untuk alasan yang diajukan.

\section{d. Dukungan masyarakat}

Dukungan Warga mengacu pada bantuan yang diberikan DJP untuk membantu warga dalam pencarian informasi (Papadomichelaki \& Mentzas, 2012). Dimensi ini berkaitan dengan interaksi masyarakat dengan karyawan help desk situs Indikator yang digunakan untuk mengukur variabel ini mengacu pada penelitian Papadomichelaki dan Mentzas (2012), yaitu :

1) Karyawan DJP menunjukkan minat yang tulus dalam memecahkan masalah pengguna.

2) Karyawan DJP memberikan balasan secepatnya ke pertanyaan pengguna.

3) Karyawan DJP memiliki pengetahuan untuk menjawab pertanyaan pengguna.

4) Karyawan DJP memiliki kemampuan untuk menyampaikan kepercayaan dan kepercayaan diri.

\section{e. Kualitas sistem}

Kualitas sistem mengacu pada pengaturan atribut fisik situs web pemerintah yang ramah pengguna, seperti kegunaan, desain situs web, kemampuan navigasi, dan modul operasi. Item pertanyaan yang digunakan untuk mengukur dimensi ini mengacu pada penelitian (Li \& Shang, 2020)

1) Saya dapat berhasil masuk ke situs website DJP setiap saat.

2) Saya dapat dengan sukses mengunjungi tautan terkait yang disediakan di beranda.

3) Dengan menggunakan situs website DJP, saya dapat berselancar dengan mudah melalui halaman web yang relevan saat melakukan transaksi $e$ government saya.

4) Modul fungsi pada situs website DJP diatur dengan cara yang ramah pengguna.

\section{Kepuasan pengguna}

Kepuasan pengguna adalah kesusuaian antara harapan seseorang dengan hasil yang diperolehnya (Ives et al., 1983). Kepuasan pengguna sistem informasi dapat dilihat dari output yang dihasilkan oleh sistem informasi online. Output tersebut berupa laporan yang dihasilkan. Item pertanyaan yang digunakan untuk mengukur dimensi ini mengacu pada penelitian (Negash et al., 2003), yaitu :

a. Situs website DJP membantu kegiatan operasional pekerjaan user/pengguna.

b. Situs website DJP dapat memenuhi kebutuhan user/pengguna.

c. Situs website DJP dapat memenuhi harapan user/pengguna.

d. Adanya dukungan dan jasa yang diberikan terhadap Situs website DJP

e. Keseluruhan Situs website DJP dan lingkungan jasa pendukungnya memberi kepuasan bagi user/pengguna.

\section{METODE PENELITIAN}

Populasi penelitian ini adalah mahasiswa aktif Program Studi Sarjana Perpajakan Fakultas Ilmu Administrasi Universtas Brawijaya di bulan September 2020. Jumlah populasi penelitian ini 698. Metode pengambilan sampel yang digunakan dalam penelitian ini adalah system random sampling. Jumlah sampel dihitung dengan rumus slovin. Berdasarkan rumus slovin jumlah sampel yang digunakan adalah 88 responden. Penelitian ini menggunakan data primer. Data diperoleh dengan melakukan kuesioner online yang dibuat melalui google form. Kuesioner disebar mulai tanggal 21 Oktober 2020-12 Oktober 2020. Metode statistik yang digunakan untuk 
menguji hipotesis yang diajukan dalam studi ini adalah Partial Least Square (PLS) dengan bantuan program SmartPLS.

\section{E. HASIL PENELITIAN \\ Karakteristik Responden}

Responden penelitian ini adalah mahasiswa aktif Program Studi Sarjana Perpajakan Fakultas Ilmu Administrasi Universtas Brawijaya. Penelitian dilakukan pada 88 responden dan didapatkan data karakteristik responden meliputi : gender, angkatan dan asal. Rincian karakteristik responden terdapat dalam Tabel 1.

Tabel 1. Karakteristik Responden

\begin{tabular}{|c|c|c|}
\hline $\begin{array}{l}\text { Karakteristik } \\
\text { Responden }\end{array}$ & $\begin{array}{c}\text { Frekuen } \\
\text { si }\end{array}$ & $\begin{array}{c}\text { Persentase } \\
(\%)\end{array}$ \\
\hline \multicolumn{3}{|l|}{ Gender } \\
\hline - Laki-Laki & 21 & $23.9 \%$ \\
\hline - Perempuan & 67 & $76.1 \%$ \\
\hline \multicolumn{3}{|l|}{ Angkatan } \\
\hline - 2016 & 2 & $2.3 \%$ \\
\hline - 2017 & 8 & $9.1 \%$ \\
\hline - 2018 & 31 & $35.2 \%$ \\
\hline - 2019 & 31 & $35.2 \%$ \\
\hline • 2020 & 16 & $18.2 \%$ \\
\hline \multicolumn{3}{|l|}{ Asal } \\
\hline • Bali & 5 & $5.7 \%$ \\
\hline - Banten & 3 & $3.4 \%$ \\
\hline - Jakarta & 7 & $8.0 \%$ \\
\hline - Jawa Barat & 3 & $3.4 \%$ \\
\hline $\begin{array}{ll}\text { - } & \text { Jawa } \\
\text { tengah }\end{array}$ & 1 & $1.1 \%$ \\
\hline $\begin{array}{ll}\text { - Jawa } \\
\text { Timur }\end{array}$ & 54 & $61.4 \%$ \\
\hline $\begin{array}{l}\text { - Kalimanta } \\
\text { n Tengah }\end{array}$ & 1 & $1.1 \%$ \\
\hline $\begin{array}{l}\text { - Kalimanta } \\
\text { n Timur }\end{array}$ & 4 & $4.5 \%$ \\
\hline $\begin{array}{l}\text { - Kepulauan } \\
\text { Riau }\end{array}$ & 1 & $1.1 \%$ \\
\hline $\begin{array}{ll}\text { - Sumatera } \\
\text { Barat } \\
\end{array}$ & 1 & $1.1 \%$ \\
\hline $\begin{array}{ll}\text { - } & \text { Sumatera } \\
\text { Selatan }\end{array}$ & 2 & $2.3 \%$ \\
\hline $\begin{array}{l}\text { - Sumatera } \\
\text { Utara }\end{array}$ & 5 & $5.7 \%$ \\
\hline $\begin{array}{l}\text { - Yogyakart } \\
\text { a }\end{array}$ & 1 & $1.1 \%$ \\
\hline
\end{tabular}

Berdasarkan Tabel 1 diketahui bahwa responden mayoritas berjenis kelamin perempuan $(76.1 \%)$ dan angakatan 2018 dan 2019. Mahasiswa berasal dari pulai Sumatra,
Jawa, Kalimantan dan Bali dengan jumlah terbanyak dari provinsi Jawa Timur (61.4\%). Semua responden pernah membuka website DJP 'pajak.go.id'.

\section{Evaluasi Model Pengukuran}

Penelitian ini menggunakan variabel reflektif dua tingkat, oleh karena itu evaluasi model pengukuran dilakukan 2 tahap, yaitu tahap Evaluasi Model Pengukuran $1^{\text {st }}$ (First) Order Confirmatory Factor Analysis dan $2^{\text {nd }}$ (Second) Order Confirmatory Factor Analysis

1. Evaluasi Model Pengukuran $1^{\text {st }}$ Order Confirmatory Factor Analysis

Pada evaluasi ini dilakukan uji validitas dan reliabilitas masing-masing dimensi . Dari hasil pengujian ini menunjukkan bahwa validitas dan reliabilitas masing-masing dimensi dalam variabel telah valid dan reliabel.

2. Evaluasi Model Pengukuran $2^{\text {nd }}$ Order Confirmatory Factor Analysis

Berikut ini adalah hasil Hasil Pengujian Path Coefficient Antar Konstruk

Tabel 2. Tabel Pengujian Path Coefficient Antar Konstruk

\begin{tabular}{|c|c|c|c|c|c|}
\hline & $\begin{array}{c}\text { Original } \\
\text { Sample } \\
(O)\end{array}$ & $\begin{array}{c}\text { Sample } \\
\text { Mean (M) }\end{array}$ & $\begin{array}{c}\text { Stand } \\
\text { ard } \\
\text { Devia } \\
\text { tion } \\
\text { (STD } \\
\text { EV) }\end{array}$ & $\begin{array}{c}\text { Standard } \\
\text { Error } \\
\text { (STERR) }\end{array}$ & $\begin{array}{c}\text { T Statistics } \\
(\mid \text { O/STERR } \mid)\end{array}$ \\
\hline$X->Y$ & 0.723 & 0.729 & 0.046 & 0.046 & 15.784 \\
\hline $\begin{array}{c}\mathbf{X}_{1}-> \\
\mathbf{X}\end{array}$ & 0.123 & 0.122 & 0.013 & 0.013 & 9.308 \\
\hline $\begin{array}{c}\mathbf{X}_{2}-> \\
\mathbf{X} \\
\end{array}$ & 0.191 & 0.193 & 0.015 & 0.015 & 12.940 \\
\hline $\begin{array}{c}\mathbf{X}_{3}-> \\
\mathbf{X}\end{array}$ & 0.326 & 0.326 & 0.021 & 0.021 & 15.496 \\
\hline $\begin{array}{c}X_{4}-> \\
X \\
\end{array}$ & 0.297435 & 0.296 & 0.019 & 0.019 & 15.744 \\
\hline $\begin{array}{c}\mathrm{X}_{5->} \\
\mathbf{X}\end{array}$ & 0.267253 & 0.267836 & $\begin{array}{c}0.020 \\
263\end{array}$ & 0.020263 & 13.189 \\
\hline
\end{tabular}

Keterangan: $\mathrm{X}=$ kualitas pelayanan; $\mathrm{Y}=$ kepuasan Pelanggan; $\mathrm{X} 1=$ efisiensi; $\mathrm{X} 2=$ reliabilitas; $\quad \mathrm{X} 3=$ kepercayaan; $\mathrm{X} 4=$ dukungan masyarakat, $\mathrm{X} 5=$ kualitas sistem

Dari hasil hubungan konstruk $1^{\text {st }}$ order dengan 2nd order yaitu $\mathrm{X}_{1}-\mathrm{X}_{5}$ dengan $\mathrm{X}$ diperoleh nilai t-statistik $>1.96$ yang menunjukkan terdapat pengaruh dimensi efisiensi, reliabilitas, kepercayaan, dukungan masyarakat dan kualitas sistem terhadap kualitas pelayanan. Kemudian dari hubungan antar konstruk second-order yaitu $\mathrm{X}$ dan $\mathrm{Y}$ juga diperoleh nilai t-statistik $>1.96$ yang memberikan kesimpulan bahwa terdapat 
pengaruh kualitas pelayanan (X) dengan kepuasan pengguna (Y) website DJP.

Untuk mengetahui besar pengaruh variabel independen terhadap variabel dependen dapat digunakan nilai $\mathrm{R}$ square dengan hasil sebagai berikut:

Tabel 2 Hasil Pengujian $R$ Square

\begin{tabular}{|c|c|}
\hline & R Square \\
\hline $\mathbf{X}$ & 0.999862 \\
\hline $\mathbf{X 1}$ & \\
\hline $\mathbf{X 2}$ & \\
\hline $\mathbf{X 3}$ & \\
\hline $\mathbf{X 4}$ & \\
\hline $\mathbf{X 5}$ & \\
\hline $\mathbf{Y}$ & 0.522410 \\
\hline
\end{tabular}

Keterangan: $\mathrm{X}=$ kualitas pelayanan; $\mathrm{Y}=$ kepuasan Pelanggan; $\mathrm{X} 1=$ efisiensi; $\mathrm{X} 2=$ reliabilitas; $\quad \mathrm{X} 3=$ kepercayaan; $\mathrm{X} 4=$ dukungan masyarakat, $\mathrm{X} 5=$ kualitas sistem

Dari nilai $R$ square dapat diketahui bahwa pada konstruk kualitas pelayanan (X) diperoleh nilai $R$ square sebesar 0.999 yang menunjukkan semua indikator yang tersusun atas lima dimesi mampu menerangkan kualitas pelayanan sebesar 99\%. Sedangkan nilai R square pengaruh kualitas pelayanan terhadap kepuasan pengguna diperoleh sebesar 0.522 yang artinya kualitas pelayanan mampu menjelaskan kepuasan pengguna sebesar $52.2 \%$, sedangkan sisanya dipengaruhi variabel lain diluar penelitian ini.

\section{PEMBAHASAN}

Kualitas pelayanan adalah upaya untuk memenuhi kebutuhan dan keinginan pelanggan (Nasution, 2004: 47). Hipotesis dalam penelitian ini menyatakan bahwa kualitas pelayanan website DJP terhadap kepuasan pengguna. Kualitan pelayanan dalam penelitian ini diukur dengan enggunakan dimensi Efisiensi, Reliabilitas, Kepercayaan, Dukungan Masyarakat, dan kualitas system.

Hasil T-statistik efisiensi terhadap kualitas pelayanan adalah 9.308 (lebih besar daripada nilai t-tabel 1.96). Hasil T-statistik Reliabilitas terhadap kualitas pelayanan adalah 12.940(lebih besar daripada nilai t-tabel 1.96). Hasil T-statistik Kepercayaan terhadap kualitas pelayanan adalah 15.496 (lebih besar daripada nilai t-tabel 1.96). Hasil T-statistik dukungan masyarakat terhadap kualitas pelayanan adalah 15.744(lebih besar daripada nilai t-tabel 1.96). Hasil T-statistik kualitas sistem terhadap kualitas pelayanan adalah 13.189 (lebih besar daripada nilai t-tabel 1.96). Hasil ini menunjukkan bahwa dimensi-dimensi tersebut telah signifikan membentuk variabel kualitas pelayanan.

Berdasarkan hasil pengujian dengan menggunakan smartPLS menunjukkan bahwa nilai t-statistik kualitas pelayanan terhadap kepuasan pengguna adalah 15.784 (lebih besar daripada nilai t-tabel 1,96) artinya hipotesis diterima. Hal ini menunjukkan bahwa semakin tinggi kualitas pelayanan, maka semakin tinggi pula tingkat kepuasan pelanggan. Hasil penelitian sejalan dengan penelitian sebelumnya (Al-Hawary \& Al-Menhaly, 2016; Ganguli \& Roy, 2011; Sung et al., 2009; Wang $\&$ Liao, 2008).

\section{F. KESIMPULAN DAN SARAN \\ Kesimpulan}

Penelitian ini bertujuan untuk mengetahui pengaruh kualitas pelayanan terhadap Website DJP Terhadap kepuasan pengguna dengan menggunakan dimensi $e$ govqual dan pengembangannya untuk mengukur kualitas pelayanan. Dimensi e govqual yang digunakan antara lain: efisiensi, reliabilitas, kepercayaan, dan dukungan masyarakat. Sedangkan dimensi tambahannya dalah Kualitas Sistem. Dari hasil penelitian ini menunjukkan bahwa masingmasing dimensi signifikan membentuk variabel kualitas system. Dan varibael kualitas Sistem berpengaruh terhadap kepuasan pengguna.

\section{Saran}

Berdasarkan penelitian ini, peneliti ingin memberikan saran kepada pihak DJP, bahwa saat ini sebaiknya DJP lebih mensosialisasikan keberadaan website DJP kepada masyarakat. Karena dengan menggunakan website, masyarakat dapat dengan mudah mendapatkan berbagai layanan dan informasi seputar perpajakan dari DJP. Hal ini didasarkan pada hasil penelitian yang menunjukkan bahwa dukungan masyarakat mendukung penilaian kualitas pelayanan. Selain itu, DJP juga harus senantiasa menjaga kualitas sistem yang dimiliki oleh website. Karena berdasarkan penelitian ini, kualitas sistem merupakan salah satu dimensi yang mendukung penilaian kualitas pelayanan. 


\section{DAFTAR PUSTAKA}

Al-Hawary, \& Al-Menhaly. (2016). The Quality of E-Government Services and its Role on Achieving Beneficiaries Satisfaction. Global Journal of Management and Business Research: Administration and Management, 16(11).

Ganguli, S., \& Roy, S. K. (2011). Generic technology-based service quality dimensions in banking: Impact on customer satisfaction and loyalty. International Journal of Bank Marketing, 29(2), 168-189.

Ives, B., Olson, M. H., \& Baroudi, J. J. (1983). The measurement of user information satisfaction. Communications of the ACM, 26(10), 785-793.

Kotler, P. (1997). Marketing Management: Analysis, Planning, Implementation and Control. Prentice-Hall Inc.

Kotler, P., \& Kevin Lane Keller. (2002). Manajemen Pemasaran (13th ed.). Erlangga.

Li, Y., \& Shang, H. (2020). Service quality, perceived value, and citizens' continuoususe intention regarding e-government: Empirical evidence from China. Information \& Management, 57(3), 103197.

Lupiyoadi Rambat. (2001). Manajemen Pemasaran Jasa Teori dan Praktik. Salemba Empat.

Nasution M Nur. (2004). Manajemen Data Terpadu. Ghalia Indonesia.

Negash, S., Ryan, T., \& Igbaria, M. (2003).
Quality and effectiveness in web-based customer support systems. Information \& Management, 40(8), 757-768.

Papadomichelaki, X., \& Mentzas, G. (2012). eGovQual: A multiple-item scale for assessing e-government service quality. Government Information Quarterly, 29(1), 98-109.

Parasuraman, A, Zeithaml, V. A., \& Berry, L. (1988). SERVQUAL: A multiple-item scale for measuring consumer perceptions of service quality. 1988, 64(1), 12-40.

Parasuraman, Anantharanthan, Zeithaml, V. A., \& Berry, L. L. (1985). A conceptual model of service quality and its implications for future research. Journal of Marketing, 49(4), 41-50.

Schlæger, J. (2013). E-government in China: Technology, power and local government reform. Routledge.

Sung, Y.-H., Liu, S.-H., Liao, H.-L., \& Liu, C.M. (2009). Service quality between egovernment users and administrators. IWAYS, Digest of Electronic Commerce Policy and Regulation, 32(4), 241-248.

Usmara, A. (2003). Strategi Baru Manajemen. Amara.

Wang, Y.-S., \& Liao, Y.-W. (2008). Assessing eGovernment systems success: A validation of the DeLone and McLean model of information systems success. Government Information Quarterly, 25(4), 717-733.

Yamit, Z. (2010). No TitleManajemen Kualitas Produk dan Jasa. Ekonisia. 